\title{
THE HISTORY OF ITALY
}




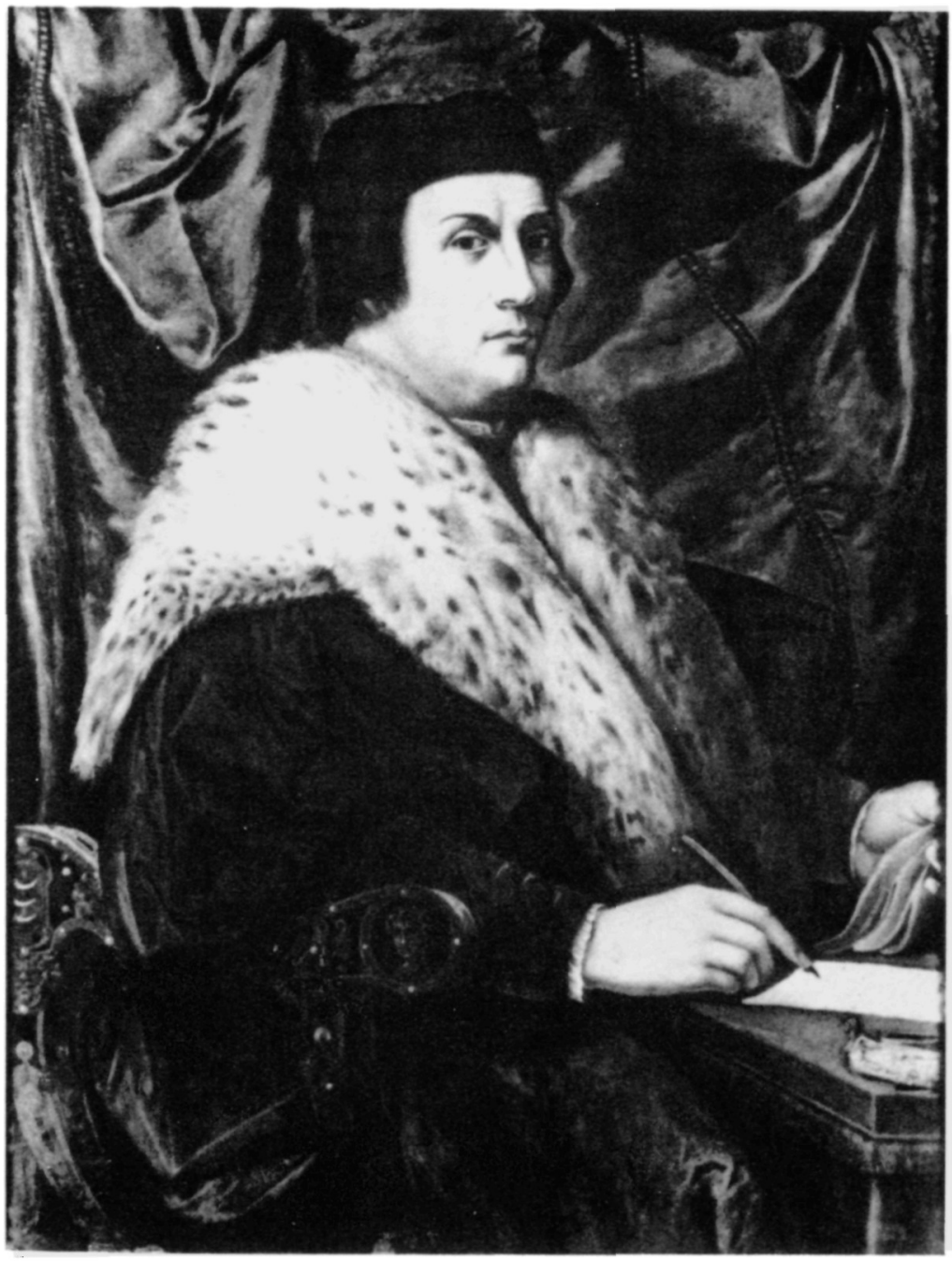

\section{PORTRAIT OF FRANCESCO GUICCIARDINI}

According to Vasari, this portrait was painted by Giuliano Bugiardini when ". . messer Francesco Guicciardini . . was in bis villa at Montici writing bis History ..." This would date the portrait toward the end of 1538 or the beginning of 1539 when the bistorian, then in bis middle fifties, was beginning bis masterwork, the incipit of which indeed may be read on the page.

(COURTESY YALE UNIVERSITY ART GALLERY, GIFT OF HANNAH D. AND LOUIS M. RABINOWITZ) 


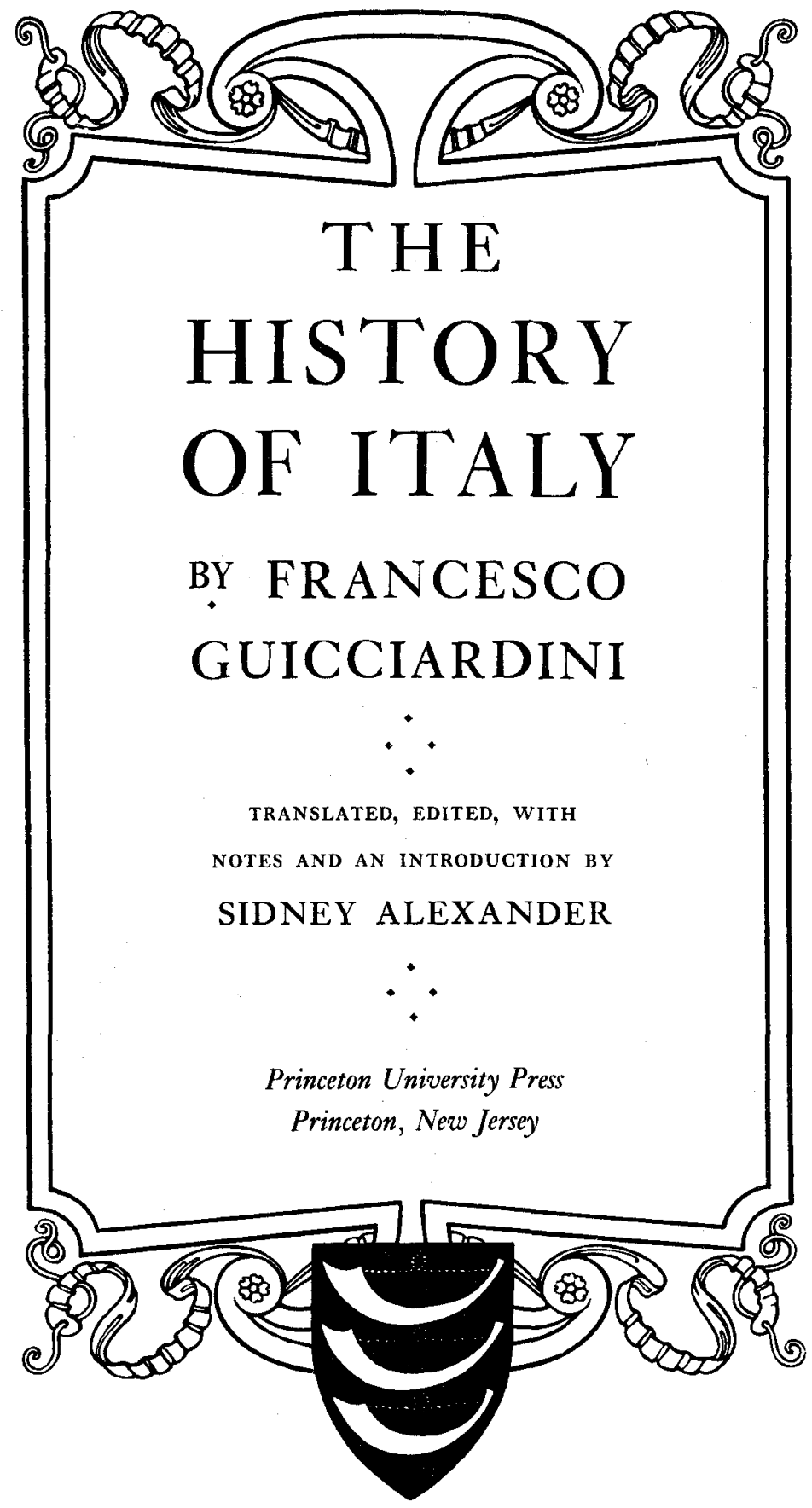


Published by Princeton University Press, 4 I William Street,

Princeton, New Jersey o $854^{\circ}$

Copyright (C) ro6g by Sidney Alexander

ALL RIGHTS RESERVED

First Macmillan hardcover edition, 1969

First Collier Books Edition, 1972

First Princeton Paperback printing, 1984

LIBRARY OF CONGRESS CATALOGING-IN-PUBLICATION DATA

Guicciardini, Francesco, $1483-1540$.

The bistory of Italy.

Translation and abridgement of: Historia d'Italia.

Previously published: New York: Macmillan, [1968, c1969]

I. Italy-History-1492-I559. I. Alexander, Sydney,

I912- . II. Title

$D G_{539-G 8 I 3} \quad 1984 \quad 945^{\prime} .06 \quad 83-43221$

ISBN o-69r-054I7-7 (alk. paper)

ISBN o-69I-00800-o (pbk.)

Princeton University Press books are printed on acid-free paper and meet the guidelines for permanence and durability of the Committee on Production Guidelines for Book Longevity of the Council on Library Resources

Printed in the United States of America 